\section{California may take hard line}

\section{Berkeley}

THE University of California (UC) is contemplating changes to its tenure policy for faculty members that would permit the removal of the "grossly incompetent". The new policy was approved by the Berkeley faculty senate last month; other campuses are considering adopting the same rules. Supporters of the new measure say it provides clear and specific criteria by which to judge faculty performance, specifying as it does dismissal rather than demotion for those judged incompetent.

US universities have been forced to tackle the issue of faculty competence, especially where older people are concerned, because federal law may soon prohibit compulsory retirement ages. Indeed, universities were exempted from the federal Age Discrimination in Employment Act of 1984, which made mandatory retirement illegal, and allowed to require retirement at 70 , but that exemption will lapse in 1993 if not renewed by Congress.

Out of a general concern over "nonproductive faculty", UC began in 1984 to review all tenured faculty members who had not appeared before a promotions or other committee for at least five years. During the first round of reviews, five people were found to be both creatively unproductive and grossly deficient in teaching.

While university rules allow that tenure may be terminated "for good cause", the

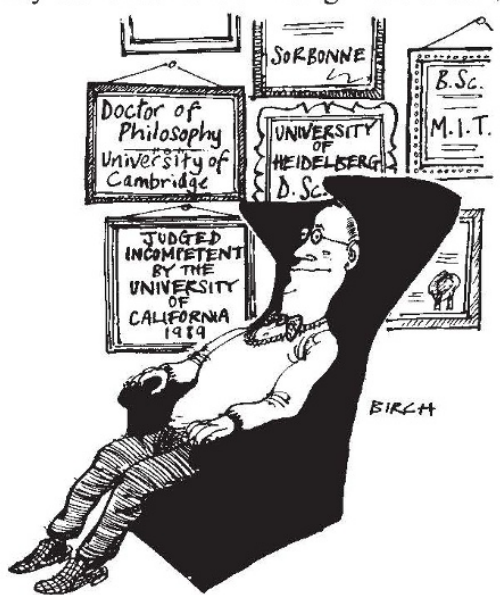

statement is so vague as to be worthless, according to UC Berkeley engineering professor Ernest Kuh. chairman of the committee responsible for the new proposals. But the new policy, he says, breaks new ground, and other universities may wish to follow.

Under the new proposals, a faculty member, to be judged incompetent, must have both "ceased to engage in serious scholarship or creative activity for a substantial period of time" and be teaching in a manner "so inadequate that it is a dis- service to students". Faculty members whose five-year evaluations produced such a record would be offered counselling and assistance, such as retraining, says English professor Ralph Rader, who presented the proposal to the academic senate last month. Only if those failed would dismissal be considered.

The purpose of the proposal is to set up machinery for dealing with incompetence that is so formalized and specific, says Rader, that it will automatically be set in motion by a negative review. But he expects that most such findings would lead not to unconditional dismissal, but to negotiated early retirement.

\section{INTERNATIONAL RELATIONS \\ Sierra Leone takes on the Soviet Union}

\section{London}

ThE Soviet Union is considering suing the Sierra Leone government for damages following the recent 8-day detention of the research vessel Akademik Mstyslav Keldysh in the port city of Freetown.

The peculiar incident began last month when the oceanography research vessel, owned by the Academy of Sciences of the USSR, arrived in Freetown to pick up some representatives of a West German company that had recently completed repairs to the two deep-water submersibles carried on the ship. The plan was to test the repaired submersibles at sea $100 \mathrm{~km}$ west of Sierra Leone, where conditions are favourable at this time of year.

But when the ship docked at Freetown, it removed the captain and several others, and questioned them in a local hotel. When the West Germans arrived in Freetown by air, they too were detained and questioned.

The Soviet foreign ministry immediately issued a strongly worded protest, calling the detention of the ship "a case of deliberate provocation". Soviet officials maintain that the Sierra Leonese government was given 72 hours' notice of the ship's intention to dock at Freetown. Other countries, including Britain, whose scientists were also aboard the vessel, seemed less inclined to become involved in the dispute.

The Sierra Leone government has not explained why the ship was detained. According to the ship's captain, the Sierra Leonese evidently believed either that the ship was on a military mission, or that it was intending to dump toxic waste within Sierra Leone's territorial waters.

The ship was eventually permitted to leave, but the normally cordial diplomatic relations between the two countries are now strained.

Vera Rich was boarded by Sierra Leone officials who
None of the five faculty members at Berkeley judged incompetent was close to retirement age, says Rader, who emphasizes that the policy is not age discriminatory. "The aim", he says, "is to deal with incompetence without reference to age."

Elizabeth Fader, of the American Association of Universities, says that concern over incompetence is rising at many universities, although most of the proposals for dealing with it have focused on incentives for early retirement, aimed at offsetting the ending of compulsory retirement ages. The National Academy of Sciences has begun a study, expected to be completed in two years, of the potential consequences for universities of the elimination of compulsory retirement.

Marcia Barinaga

\section{SOUTH AFRICA}

\section{Kane-Berman wins reinstatement}

\section{Cape Town}

DR Jocelyn Kane-Berman, who was dismissed as superintendent of Groote Schuur Hospital in November after naming Nelson Mandela as her choice of premier in a newspaper interview (see Nature 338, 4; 1989), has been reinstated in her post with immediate effect.

The Administrator of the Cape Province, Mr Gene Louw (under whose aegis hospital administration falls) said on 10 March: "I can merely say that I took the initiative to bring it about. I thought it was in the best interests of Groote Schuur Hospital." This complete change in the government's attitude seems to be related to an appeal by Kane-Berman to have her reinstatement ordered by the courts. She had already served papers on Louw and other provincial officials, and her case was due to be heard in the Cape Supreme Court on 20 April. In December, Louw described Kane-Berman's removal as "final from the outset", and last month in parliament the Minister of Health and Population Development. Dr Willie van Niekerk, refused to intervene.

Kane-Berman has now agreed to withdraw the legal proceedings, and agreement has been reached on costs. She has. however, retracted her comments in the weekend newspaper in which she made her "controversial" statement, and has tendered her apology towards those persons and offices that were embarrassed. It is rumoured that South Africa's ailing State President, P.W. Botha personally ordered Kane-Berman's removal, although this has been denied by government spokesmen.

Kane-Berman, who described herself as "quite delighted" by her reinstatement. said: "I'm very pleased that the matter has been amicably resolved." Michael Cherry 